\title{
Analiza poziomu zadowolenia z opieki badanych pacjentek oddziału położniczo - neonatologicznego w zależności od wybranych zmiennych socjodemograficznych
}

\section{Satisfaction care analysis of the examined patients of the obstetric-neonatological ward depending on the selected sociodemographic variables}

DOROTA KOCHMAN ${ }^{1}$ PAULINA WOJASIŃSKA²

\author{
1Państwowa Wyższa Szkoła Zawodowa we Włocławku, Instytut Nauk o Zdrowiu, \\ ID: https://orcid.org/0000-0002-3221-712X \\ ${ }^{2}$ Oddział dziecięcy, pododdział neonatologiczny SPZOZ Radziejów \\ DOI: : http://dx.doi.org/10.21784//wP.2019.001 \\ ISSN: 2451-1846
}

\section{Streszczenie:}

Wstęp. Poziom zadowolenia pacjentów ze sprawowanej opieki odgrywa coraz większą rolę wocenie jakości usług medycznych. Potrzeba prowadzenia badań w tym zakresie wynika nie tylko z rozwoju medycyny, konkurencji pomiędzy ośrodkami opieki medycznej, ale przede wszystkim z konieczności szukania optymalnych rozwiązań w sprawowaniu opieki nad pacjentem i dążeniu do ciągłego rozwoju kadry medycznej.

Cel. Celem pracy jest analiza poziomu zadowolenia z opieki badanych pacjentek oddziału położniczo - neonatologicznego.

Materiał i metody. W pracy wykorzystano metodę sondażu diagnostycznego oraz metodę szacowania, jako technikę - ankietowanie i skalę szacunkową. Narzędziem uczyniono własny kwestionariusz ipolską wersję skali zadowolenia $\mathrm{z}$ opieki NEWCASTLE (wybrane aspekty). W przeprowadzonych badaniach udział wzięło 50 osób. 
Wyniki. Średni poziom zadowolenia z opieki pielęgniarskiej oddziale oscylował w granicy maksymalnej ilości punktów do zdobycia, co oznacza, że prawie wszystkie $\mathrm{z}$ ankietowanych kobiet były bardzo zadowolone ze sprawowanej nad nimi i ich dziećmi opieki.

Wnioski. Na poziom zadowolenia $\mathrm{z}$ opieki i pozyskiwania informacji od personelu nie mają istotnego wpływu wybrane zmienne socjodemograficzne (wiek, wykształcenie, miejsce zamieszkania), czas hospitalizacji i korzystanie ze wsparcia ze strony pielęgniarek.

Słowa kluczowe: jakość opieki, skala Newcastle, zadowolenie z opieki

\begin{abstract}
:
Introduction. The level of patient satisfaction in medical care plays an increasingly important role in evaluating the quality of medical services. The need for research in this area results from not only the development of medicine but also the competition between medical centers but primarily from the need to find optimal solutions in patient care and the pursuit of continuous development of healthcare personnel.

Aim. The aim of the study is to analyze the care satisfaction level of the examined patients of the obstetric-neonatologicalward.

Material and methods. The study uses the method of diagnostic survey and the method of estimation as a technique - questionnaire and estimation scale. Author's questionnaire and the polish version of the NEWCASTLE care satisfaction scale was selected as a tool (selected aspects). A total of 50 particicpants took part in the research.

Results. The average level of satisfaction with nursing care oscillated around the limit of the maximum number of points to be won, which means that almost all of the respondents were very satisfied with the care provided as well as childcare.
\end{abstract}

Conclusions. Sociodemographic variables (age, education, place of residence), the time of hospitalization and the use of the support of the healthcare personnel do not affect the satisfaction care level.

Keywords: quality of care, Newcastle, care satisfaction

\title{
Wstęp
}


Neonatologia jako nauka zajmuje się patofizjologią okresu noworodkowego tj. schorzeniami noworodków, wrodzonymi wadami, a także fizjologicznym rozwojem dzieci aż do momentu zakończenia rozwoju narządów (2 rok życia). Samo słowo „neonatologia” pochodzi od łacińskiego neonatus, co $\mathrm{w}$ bezpośrednim tłumaczeniu znaczy nowonarodzony. Nauka ta jest stosunkowo młoda specjalnością medycyny $[1,2]$.

Standardy opieki nad noworodkiem i położnicą w okresie okołoporodowym regulowane są przez Rozporządzenie Ministra Zdrowia $\mathrm{z}$ dnia 16 sierpnia 2018r. w sprawie standardu organizacyjnego opieki okołoporodowej [3].

Celem pracy jest analiza poziomu zadowolenia $\mathrm{z}$ opieki pacjentek oddziału położniczo - neonatologicznego w Samodzielnym Publicznym Zakładzie Opieki Zdrowotnej w Radziejowie.

\section{Materiał i metody}

W pracy wykorzystano metodę sondażu diagnostycznego oraz metodę szacowania, jako technikę- ankietowanie i skalę szacunkową.Narzędziem uczyniono polską wersję skali zadowolenia z opieki NEWCASTLE (wybrane aspekty). Skala ta służy do oceny doświadczeń związanych $\mathrm{z}$ opieką pielęgniarskiej oraz satysfakcji pacjenta $\mathrm{z}$ tej opieki. Drugim narzędziem badawczym jest kwestionariusz ankiety własnego autorstwa.

Wyniki przeprowadzanych badań zostały poddane analizie statystycznej. Występowanie współzależności między zmiennymi, obliczone zostało za pomocą współczynnika korelacji R Spearmana. Współczynnik ten, służy do opisu sił korelacji występujących pomiędzy dwoma cechami, gdy mają one charakter jakościowy i istnieje możliwość uporządkowania obserwacji empirycznych w określonej kolejności lub w sytuacji gdy mamy do czynienia z cechami ilościowymi. Zastosowano również nieparametryczny test U Manna - Whitneya w celu oceny różnic jednej cechy pomiędzy 
dwoma grupa. W pracy wykorzystany został także test rang Kruskala - Wallisa, który stosowany jest do porównywania wielu niezależnych grup. Jako hipotezę zerową przyjęto, brak różnic $\mathrm{w}$ badanych grupach. Jako poziom istotności statystycznej przyjęto $p>0,05$.

W przeprowadzonych badaniach udział wzięło 50 osób. Średnia wieku badanych wyniosła 28 lat. Najmłodsza z respondentek miała 18 lat, najstarsza 41 . Odchylenie standardowe wynosi $16,7 \%$ co świadczy o przeciętnym zróżnicowaniu wieku.

Respondenci zostali podzieli na trzy grupy wiekowe:

o 25 lat - grupę stanowi 16 osób (32\%), 6-30 lat - grupę stanowi 19 osób (38\%), powyżej 30 lat - grupę stanowi 15 osób co daje (30\%).

Najliczniejszą grupę badanych stanowiły osoby pomiędzy 26, a 30 rokiem życia, najmniej liczną osoby po 30 roku życia.

Respondenci podzieleni zostali na grupy ze względu na wykształcenie. Wykształcenie podstawowe posiadała jedna osoba (2\% badanych), wykształcenie zawodowe dotyczyło 10 osób (20\%), średnim legitymowały się 24 pacjentki (48\%) a wyższym 15 (30\%) spośród ankietowanych. Najliczniejszą grupę stanowiły pacjentki $\mathrm{z}$ wykształceniem średnim, a najmniej liczną $\mathrm{z}$ podstawowym. Do celów dalszej analizy osoba ta została zakwalifikowana do grupy $\mathrm{z}$ wykształceniem zawodowym.

Zdecydowana większość pacjentek nie uczyła się dalej (44 osoby, 88\%). Średnia wieku ukończenia nauki przez pacjentki biorące udział w badaniu wynosiła niespełna 22 lata. Maksymalny wiek respondentek w chwili ukończenia nauki wynosił 32 lata, minimalny 18 lat. Odchylenie standardowe wyniosło $16,1 \%$ co świadczy o przeciętnym zróżnicowaniu wieku badanych w czasie zakończenia edukacji.

Średnia ilość nocy, które respondentki spędziły w oddziale wyniosła 4. Najdłuższy pobyt trwał 8 nocy, najkrótszy 2. Odchylenie standardowe wynosiło $36,4 \%$ co świadczy o znacznym zróżnicowaniu ilości dni spędzonych w oddziale przez pacjentki. Połowa badanych 
(25 osób, 50\%) w oddziale spędziły do 3 nocy. Pobyt pozostałych był dłuższy.

Ponad połowa badanych (26 osób,52\%) uważała, że nie miała wyznaczonej konkretnej pielęgniarki sprawującej nad nimi opiekę. Z kolei 19 kobiet (38\%) nie było pewnych tego faktu, natomiast 5 osób (10\%) uważało, że opieka nad nimi sprawowana była przez konkretnie wyznaczoną pielęgniarkę.

Zdecydowaną większość respondentek stanowiły kobiety zamężne - 36 osób (76\%). W gronie badanych jedna (2\%) deklarowała stan cywilny jako rozwiedziona. Pozostała grupa czyli $22 \%$ (11 osób) to panny.

Większość kobiet (35 osób,70\%) biorących udział w badaniu zamieszkiwało na wsi, a 15 osób (30\%) w mieście.

\section{Wyniki}

Całościowa ocena opieki pielęgniarskiej otrzymanej w oddziale neonatologicznym w skali 1-7 zawierała się w granicy 4-7 pkt. Połowa badanych sprawowaną opiekę oceniła na 6 pkt., co oznacza ocenę bardzo dobrą. Jedna osoba (2\%) w oddziale oceniła jako wystarczającą - 4pkt. Należy zwrócić uwagę na fakt, iż odpowiedzi: zła, bardzo zła, okropna nie zostały wybrane przez żadną spośród ankietowanych kobiet do oceny uzyskanej opieki. 


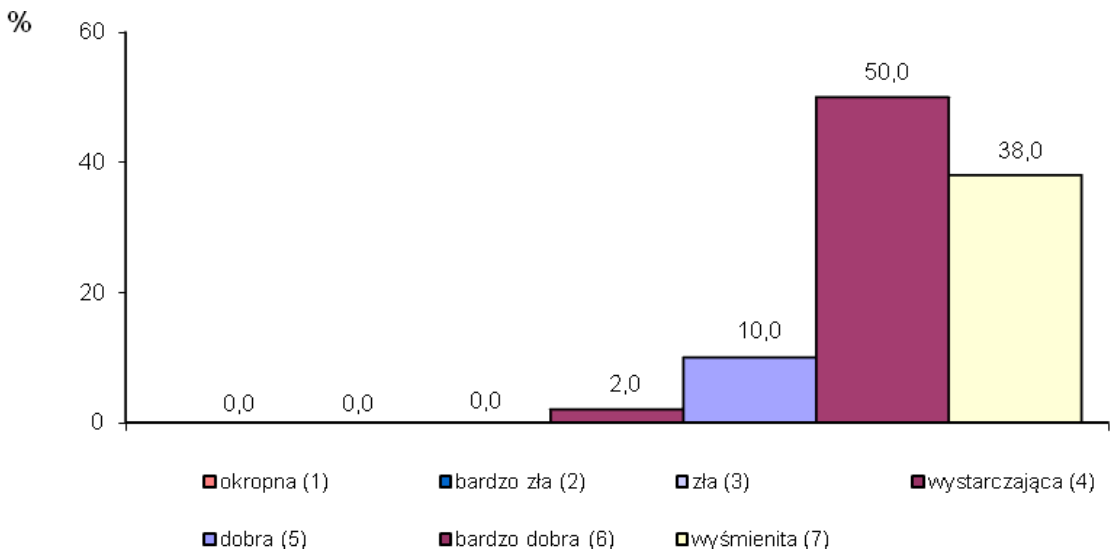

Rycina 1.Rozkład oceny opieki pielęgniarskiej otrzymanej w oddziale przez badane.

Źródło: wynik badań własnych

Ocena pobytu w oddziale mieściła się w granicy 4-7 pkt. Ponad połowa ( $52 \%$ osób) oceniła pobyt w oddziale na 6 pkt. (bardzo dobrze), a tylko 1 spośród ankietowanych kobiet (2\%) jako wystarczający.

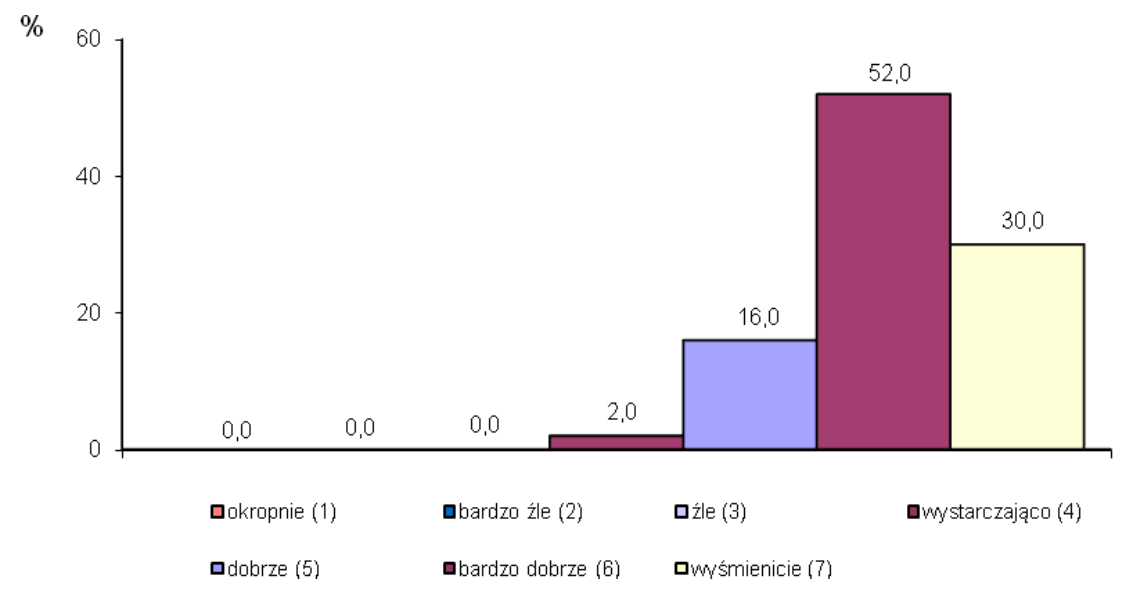

Rycina 2.Rozkład oceny pobytu badanych w oddziale.

Źródło: wynik badań własnych 
Średnia ocena opieki pielęgniarskiej $\mathrm{w}$ oddziale wynosiła 6,24pkt.(bardzo dobrze) $\mathrm{z}$ kolei średnia ocena pobytu $\mathrm{w}$ oddziale wynosiła 6,1pkt. (co również, mieści się w ocenie bardzo dobrej).

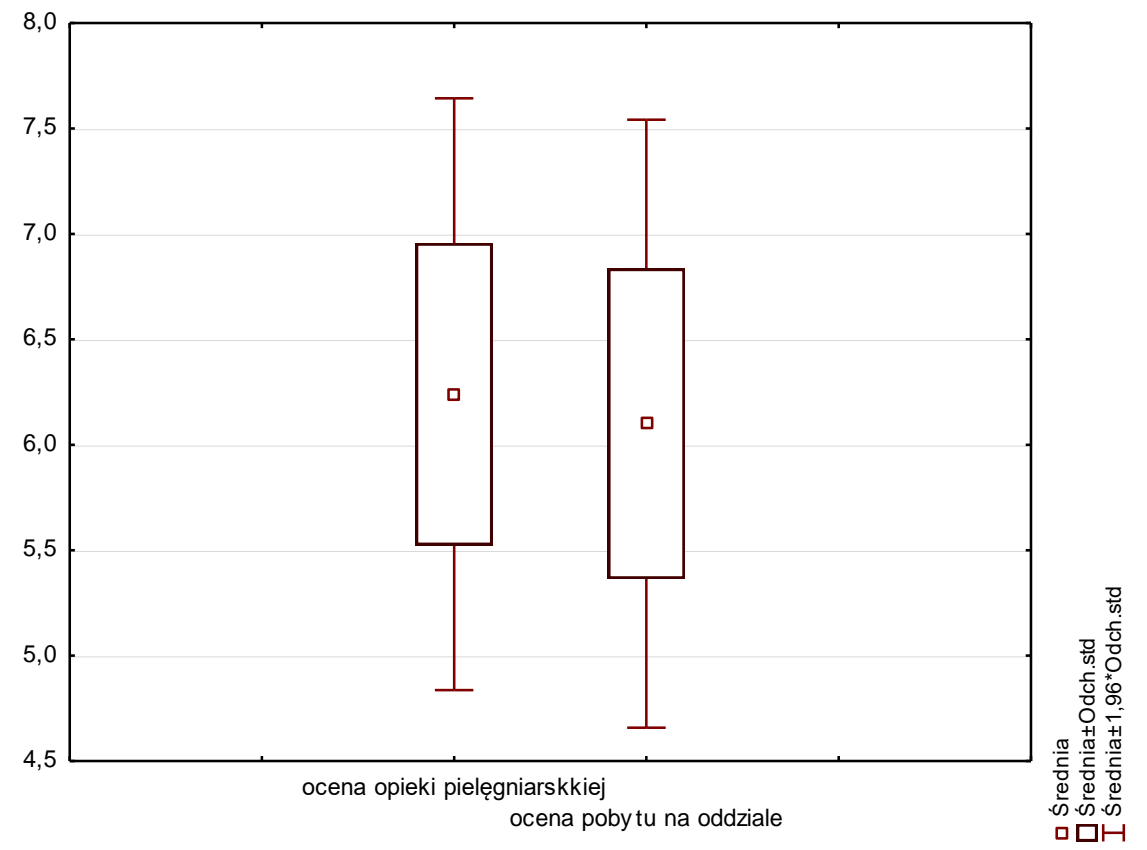

Rycina 3. Rozkład średnich oceny opieki pielęgniarskiej otrzymanej przez badane oraz pobytu w oddziale.

Źródło: wynik badań własnych

Poziom zadowolenia $\mathrm{z}$ opieki pielęgniarskiej oraz pozyskiwanych od personelu informacji badany był za pomocą autorskiego kwestionariusza ankiety. Większość badanych (33 osoby) oceniło pierwszy kontakt $\mathrm{z}$ personelem pracującym $\mathrm{w}$ oddziale neonatologicznym jako bardzo dobry, 15 kobiet (30\%) dobry, 2 uczestniczki (4\%) jako przeciętny. 
Zdecydowana większość tj. 98\% badanych stwierdziła, że pielęgniarki zatrudnione $\mathrm{w}$ oddziale neonatologicznym były dla nich życzliwe.

Większość badanych (39 osób, 78\%) kompetencje personelu zatrudnionego w oddziale oceniło jako bardzo dobre, pozostałe (11osób, 22\% ) określiły je jako dobre.

Prawie wszystkie respondentki (48 osób, 96\%) stwierdziło, że pielęgniarki odpowiadały na każde zadane przez nie pytanie.

Zarówno pracę personelu na dyżurach nocnych i dziennych najwięcej osób oceniło jako bardzo dobrą. Pracę na dyżurach dziennych $\mathrm{w}$ ten sposób oceniło 68\% ankietowanych (34 osoby), na dyżurach nocnych natomiast $64 \%$ (32 osoby). Jako dobrą pracę zarówno na dyżurach dziennych jak i nocnych oceniło 16 kobiet (32\%). Najniższa ocena (pielęgniarki pracowały przeciętnie) przyznana została pracy pielęgniarek na dyżurach nocnych przez 2 (4\%) spośród ankietowanych.

Prawie wszystkie respondentki (98\% -49 osób) stwierdziły, że personel pielęgniarski zatrudniony w oddziale przekazywał informacje na temat dalszej opieki nad noworodkiem w sposób jasny, zrozumiały. Jedna osoba (2\%) uważała, że informacje nie były przekazywane $\mathrm{w}$ odpowiednio zrozumiały sposób. Zdecydowana większość badanych stwierdziła, że pielęgniarki udzielały informacji na temat konkretnych działań dotyczących opieki nad noworodkiem. Informację na temat czynników ryzyka śmierci łóżeczkowej od personelu uzyskało 37osób (74\%); bezpiecznego układania noworodka 44 osoby ( $88 \%$ ); udzielenia pierwszej pomocy w stanie zagrożenia życia dziecka 29 osób (58\%); bezpiecznego przenoszenia noworodka 46 osób (92\%); prawidłowej pielęgnacji kikuta pępowiny 47 osób (94\%); przewijania noworodka 42 osoby (84\%); technik karmienia piersią 46 osób (92\%); korzyści płynących z karmienia piersią 45 osób (90\%); na temat postępowania w przypadku uszkodzenia brodawek sutkowych 36 (72\%); miejsca gdzie mogą się zgłosić po pomoc $\mathrm{w}$ sytuacji wystąpienia trudności $\mathrm{w}$ karmieniu 
po opuszczeniu szpitala 29 osób (58\%); bezpiecznego ubierania/ rozbierania noworodka 42 osoby (84\%); bezpiecznej kąpieli noworodka 41 osób (82\%).

Poniżej przedstawiono odpowiedzi badanych na temat wymienionych działań dotyczących opieki nad noworodkiem:

- Otrzymanie przez badane formacji na temat czynników ryzyka śmierci łóżeczkowej - 37 osób / 74\% ankietowanych.

- Otrzymywanie przez badane informacji na temat bezpiecznego układania noworodka - 44 osób / 88\% ankietowanych.

- Otrzymywanie przez badane informacji na temat metod pierwszej pomocy w przypadku zagrożenia życia dziecka - 29 osób / 58\% ankietowanych.

- Otrzymywanie przez badane informacji na temat bezpiecznego przenoszenia noworodka - 46 osób / 92\% ankietowanych.

- Otrzymywanie przez badane informacji na temat prawidłowego dbania o kikut pępowinowy noworodka - 47 osób / 94\% ankietowanych.

- Otrzymywanie przez badane informacji na temat bezpiecznych sposobów przewijania noworodka - 42 osób / 84\% ankietowanych.

- Otrzymywanie przez badane informacji na temat technik karmienia piersią - 46 osób / 92\% ankietowanych.

- Otrzymywanie przez badane informacji na temat korzyści płynących z karmienia piersią- 46 osób / 92\% ankietowanych.

- Otrzymywanie przez badane informacji na temat postępowania w przypadku uszkodzenia brodawek sutkowych- 36 osób / 72\% ankietowanych.

- Otrzymywanie przez badane informacji, gdzie można się zgłosić w celu uzyskania pomocy w sytuacji wystąpienia trudności w karmieniu piersią po opuszczeniu szpitala- 29 osób / 58\% ankietowanych. 
- Otrzymywanie przez badane informacji na temat bezpiecznego ubierania / rozbierania noworodka - 42 osób / 84\% ankietowanych.

- Otrzymywanie przez badane informacji na temat bezpiecznej kąpieli noworodka- 41 osób / 82\% ankietowanych.

Ocena poziomu zadowolenia $\mathrm{z}$ opieki pielęgniarskiej w oddziale w skali 0-10 pkt. oscylowała w granicy $5-10$ pkt.z pominięciem 6 pkt. Najliczniejsza grupa badanych (30 osób - 60\% ) oceniła swój poziom zadowolenia z opieki maksymalnie wysoko (10 pkt.). Zauważyć trzeba również, że 9 pkt. przyznało 11 kobiet (22\%).8 lub 7 punktów przyznało po $8 \%$ ankietowanych. Najniższą ocenę ( 5 pkt.) przyznano tylko jeden raz.

Średnia ocena poziomu zadowolenia z opieki pielęgniarskiej w oddziale neonatologicznym wyniosła 9,28 pkt., co oznacza, że zdecydowana większość kobiet była całkowicie zadowolona z opieki. 


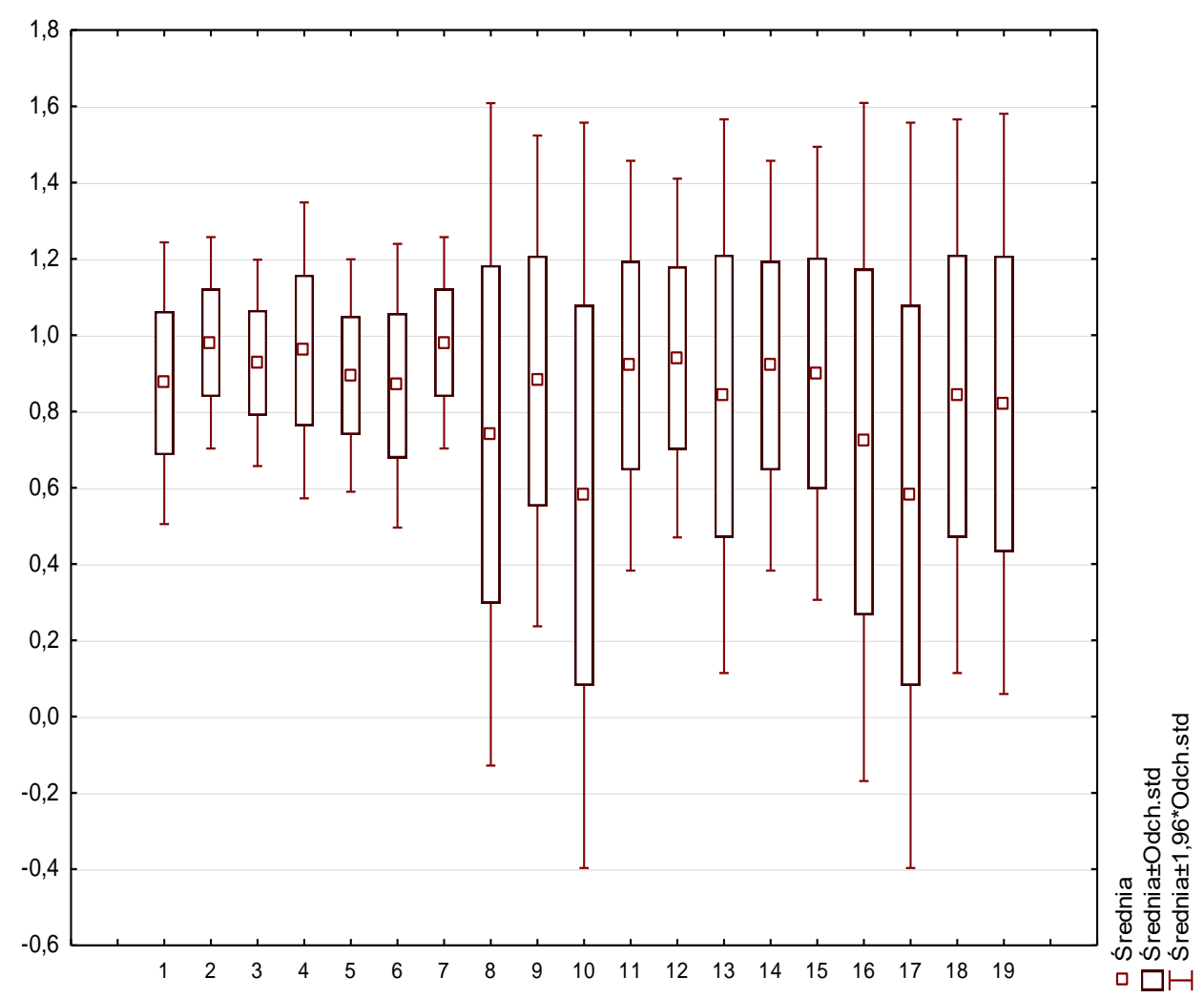

Rycina 4.Rozkład średnich wyników poszczególnych aspektów zadowolenia badanych $\mathrm{z}$ opieki pielęgniarskiej $w$ oddziale neonatologicznym.

Źródło: wynik badań własnych

$\mathrm{Nr} \quad$ treści

1 jak ocenia Pani swój pierwszy kontakt z pielęgniarkami/ położnymi pracującymi w pododdziale neonatologicznym ?

2 czy pielęgniarki/ położne pracujące $\mathrm{w}$ oddziale były zawsze życzliwe w stosunku do Pani ?

3 jak ocenia Pani poziom kompetencji pielęgniarek/ położnych zatrudnionych w oddziale? 
$4 \quad$ czy personel pielęgniarski/ położniczy udzielał odpowiedzi na każde Pani pytanie?

5 jak ocenia Pani prace pielęgniarek/ położnych pracujących na dyżurach dziennych?

6 jak ocenia Pani pracę pielęgniarek/ położnych pracujących na dyżurach nocnych?

$7 \quad$ czy informacje na temat dalszej opieki (sprawowanej przez Panią w domu) nad noworodkiem przekazywane były przez personel w sposób jasny, zrozumiały dla Pani ?

8 czy została Pani poinformowana o czynnikach ryzyka śmierci łóżeczkowej ?

9 czy udzielono Pani informacji na temat bezpiecznego układania noworodka?

10 czy udzielono Pani informacji na temat metod pierwszej pomocy w przypadku stanu zagrożenia życia noworodka ?

11 czy udzielono Pani informacji na temat bezpiecznego przenoszenia noworodka?

12 czy udzielono Pani informacji na temat prawidłowego dbania o kikut pępowiny noworodka?

13 czy udzielono Pani informacji na temat bezpiecznych sposobów przewijania noworodka?

14 czy udzielono Pani informacji na temat technik karmienia piersią?

15 czy została Pani poinformowana o korzyściach płynących $\mathrm{z}$ karmienia piersią ?

16 czy udzielono Pani informacji na temat postępowania w przypadku uszkodzeń brodawek sutkowych ?

17 czy została Pani poinformowana o tym, gdzie można zgłosić się o pomoc $\mathrm{w}$ sytuacji wystąpienia trudności $\mathrm{w}$ karmienia piersią po opuszczenia szpitala?

18 czy udzielono Pani informacji na temat bezpiecznego ubierania/ rozbierania noworodka? 
19 czy udzielono Pani informacji na temat bezpiecznej kąpieli dziecka?

W celu sprawdzenia, jak kształtowały się wyniki zagadnień dotyczących oceny opieki pielęgniarskiej, kompetencji pracowników oraz udzielanych przez personel informacji, ponownej weryfikacji poddano pytania od 1 do $19 \mathrm{z}$ kwestionariusza ankiety. W celu utrzymania jednolitego zakresu punktacji - do 1 pkt., w pytaniach 1,3, 5 i 6 przyjęto następującą kwalifikację punktową: źle - 0 pkt., przeciętnie 0,33 pkt., dobrze - 0,67 pkt., bardzo dobrze - 1 pkt. Ustalono, że $\mathrm{z}$ analizowanych aspektów, najwyższe $\mathrm{w}$ stosunku do wartości oczekiwanej wskaźniki otrzymano w aspektach: życzliwości personelu pracującego w oddziale (pytanie nr 2 - 0,98 pkt.), jasności przekazywania informacji na temat dalszej opieki nad noworodkiem (pytanie nr7 - 0,98 pkt.), udzielania odpowiedzi przez personel na każde zadane pytanie (pytanie nr $4-0,96$ pkt.), udzielenia informacji na temat prawidłowego dbania o kikut pępowinowy (pytanie nr 12 0,94 pkt.) oraz kompetencji personelu zatrudnionego $\mathrm{w}$ oddziale (pytanie nr3 -0,94 pkt.). Najniższe wskaźniki uzyskano w pytaniach dotyczących bezpiecznej kąpieli noworodka (pytanie nr $19-0,82$ pkt.), udzielenia informacji na temat czynników ryzyka śmierci łóżeczkowej (pytanie nr 8 - 0,74 pkt.), udzielenie informacji na temat postępowania $\mathrm{w}$ przypadku uszkodzenia brodawek sutkowych (pytanie nr 16-0,72 pkt.), udzieleniu informacji na temat miejsca, gdzie można zgłosić się $\mathrm{W}$ przypadku wystąpienia trudności w karmieniu piersią po opuszczeniu szpitala (pytanie nr 17 - 0,58 pkt.) oraz udzielenie informacji na temat metod pierwszej pomocy w przypadku stanu zagrożenia życia dziecka (pytanie nr 10 -0,58 pkt.).

Średnia ocena opieki pielęgniarskiej w oddziale, kompetencji personelu oraz udzielania informacji wyniosła 16,16 pkt. $(85,1 \%)$ co interpretować należy jako ocenę dobrą. 

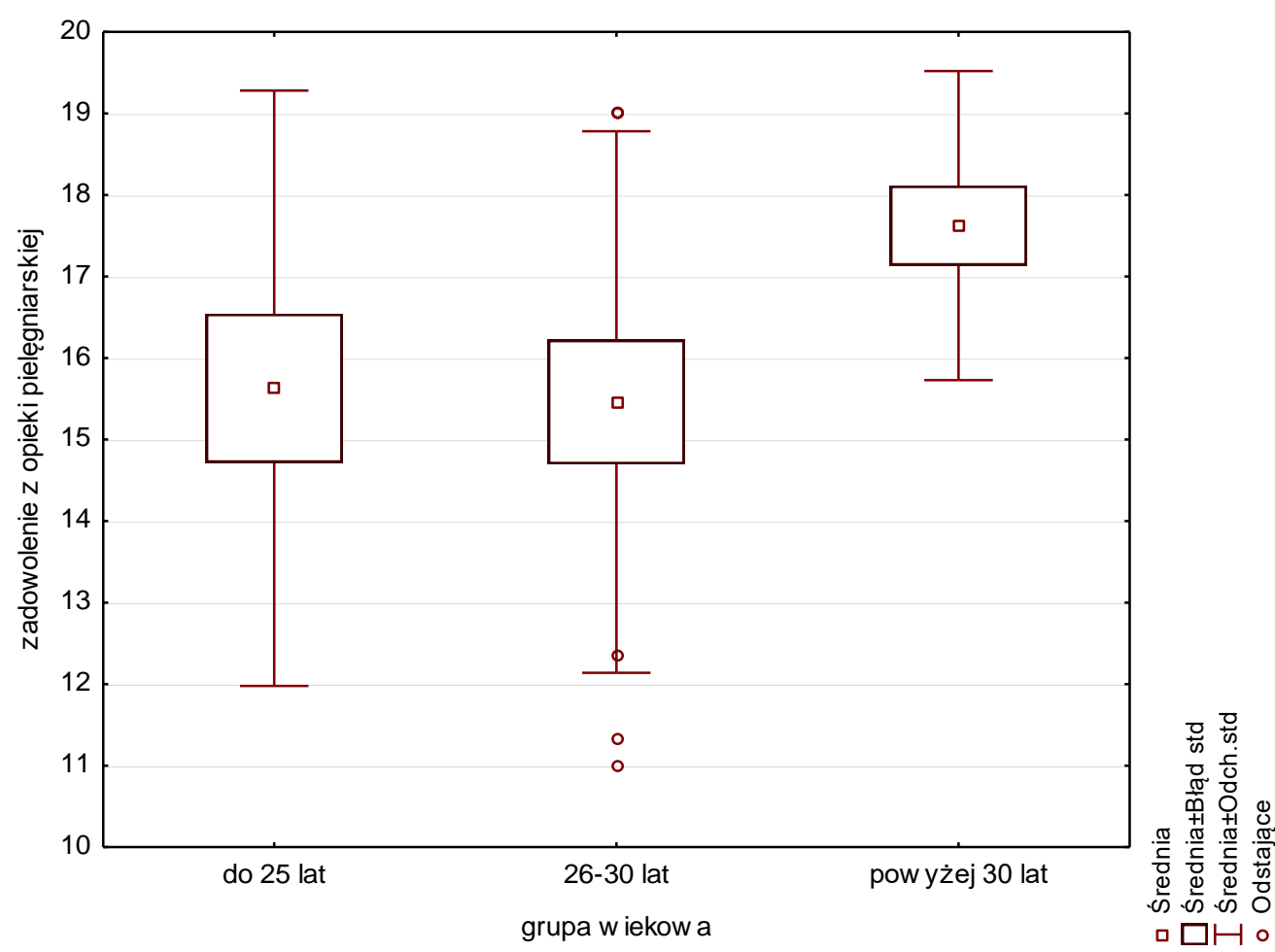

Rycina 5. Rozkład średnich punktacji zadowolenia badanych z opieki pielęgniarskiej w oddziale neonatologicznym.

Źródło: wynik badań własnych

\section{Dyskusja}

Opieka sprawowana w oddziale szpitalnym nad noworodkiem może pośrednio wpłynąć na zakres opieki realizowanej przez rodziców/opiekunów w domu. Oddział noworodkowy jest zatem tym miejscem, w którym szczególną uwagę należy zwrócić na zadowolenie badanych $\mathrm{z}$ opieki pielęgniarskiej. Każda $\mathrm{z}$ pacjentek oddziału położniczego powinna zostać optymalnie przygotowana do opieki nad noworodkiem w domu. W przeprowadzonych badaniach szczególną 
uwagę zwrócono na wpływ wybranych zmiennych socjodemograficznych, czas trwania hospitalizacji oraz korzystanie ze wsparcia ze strony pielęgniarek na postrzeganie jakości opieki sprawowanej przez personel medyczny.

Przeanalizowano oceny zadowolenia z opieki pielęgniarskiej w poszczególnych grupach wiekowych respondentek. Najwyższy poziom zadowolenia $\mathrm{z}$ opieki pielęgniarskiej wykazały badane $\mathrm{w}$ wieku powyżej 30 lat. Średnia ocena wynosi 17,62 pkt. Najniższy poziom zadowolenia wykazały pacjentki $\mathrm{w}$ wieku 26-30 lat - średnia 15,46 pkt.

Wiek badanych, nie pozostawał $\mathrm{w}$ istotnej statystycznie korelacji $\mathrm{z}$ oceną zadowolenia $\mathrm{z}$ opieki pielęgniarskiej $\mathrm{w}$ oddziale ( $p>0,05)$. Wynik zarejestrowano na granicy istotności statystycznej $(p=0,077)$.

Przeanalizowano oceny zadowolenia z opieki pielęgniarskiej w zależności od poziomu wykształcenia badanych. Największe zadowolenie z opieki prezentowały osoby z wykształceniem wyższym - średnia wyniosła 16,63 pkt. Respondentki z wykształceniem zawodowym uzyskały 14,43pkt., z średnim natomiast, uzyskały zadowolenie $\mathrm{z}$ opieki na średnim poziomie 16,63 pkt.

Wykształcenie badanych nie pozostawało w istotnej statystycznie korelacji $\mathrm{z}$ oceną zadowolenia respondentów z opieki pielęgniarskiej w oddziale $(p>0,05)$ - $(p=0,171)$.

Przeanalizowano oceny zadowolenia z opieki pielęgniarskiej w zależności od ilości nocy spędzonych przez respondentki w oddziale. Wyższy poziom zadowolenia z opieki uzyskały badane przebywające w oddziale powyżej 3 nocy - średnia 16,54 pkt. Średnia osób przebywających w oddziale do 3 nocy wynosiła 15,78 pkt.

Ze względu na poziom istotności $(p>0,05)$, nie odnotowano istotnej statystycznie różnicy w punktacji pomiędzy okresem trwania hospitalizacji a zadowoleniem z opieki $(p=0,295)$.

Przeanalizowano oceny zadowolenia $\mathrm{z}$ opieki pielęgniarskiej w zależności od miejsca zamieszkania badanych. Wyższe zadowolenie 
z opieki pielęgniarskiej uzyskały badane mieszkające w mieście średnia 16,65 pkt. w porównaniu do 15,96 pkt. uzyskanych przez mieszkanki wsi.

Ze względu na poziom istotności $(\mathrm{p}>0,05)$ nie odnotowano istotnej statystycznie zależności pomiędzy miejscem zamieszkania ankietowanych a uzyskanym przez nie poziomem zadowolenia $\mathrm{z}$ opieki $(\mathrm{p}=0,446)$.

Przeanalizowano oceny zadowolenia $\mathrm{z}$ opieki pielęgniarskiej w zależności od świadczeń sprawowanych przez wyznaczoną pielęgniarkę. Najwyższy poziom zadowolenia $\mathrm{z}$ opieki dotyczył ankietowanych, nie posiadających wyznaczonej do sprawowania nad nimi opieki pielęgniarki. Średnia punktacja zadowolenia $\mathrm{z}$ opieki wyniosła 16,41. Pacjentki, którym wyznaczono pielęgniarkę do sprawowania nad nimi opieki uzyskały średni wynik na poziomie 15 pkt. Respondentki, które nie były pewne, czy opiekę nad nimi sprawuje określona pielęgniarka uzyskały średni wynik 16,13pkt.

Wyznaczenie konkretnej pielęgniarki do sprawowania opieki na ankietowanymi nie różnicowało $\mathrm{w}$ sposób istotny zadowolenia $\mathrm{z}$ opieki pielęgniarskiej $(\mathrm{p}=0,376)$.

Średni poziom zadowolenia $\mathrm{z}$ opieki pielęgniarskiej oddziale oscylował $\mathrm{w}$ granicy maksymalnej ilości punktów do zdobycia, co oznacza, że prawie wszystkie $\mathrm{z}$ ankietowanych kobiet były bardzo zadowolone ze sprawowanej nad nimi i ich dziećmi opieki. Badania własne wykazały, że wybrane zmienne socjodemograficzne, a także czas hospitalizacji i korzystanie ze wsparcia ze strony pielęgniarek nie mają istotnego wpływu na poziom zadowolenia $\mathrm{z}$ opieki pielęgniarskiej.

Do podobnych wniosków doszły Kołpa, Jurkiewicz i Sobyraw badaniach dotyczących zadowolenia z opieki pielęgniarskiej w oddziale chirurgii jednego dnia. Zauważyły one, że wiek, miejsce zamieszkania oraz poziom wykształcenia nie mają istotnego statystycznie wpływu na ocenę zadowolenia z opieki [4]. Szpringer, Chmielewski, Kosecka, Sobczyk oraz Komendacka w swoich badaniach 
na temat poziomu zadowolenia pacjenta jako jednego $\mathrm{z}$ aspektów jakości opieki medycznej zauważyli, że istnieje statystycznie istotny związek pomiędzy satysfakcji pacjentów $\mathrm{z}$ opieki a ich statusem zawodowym, płcią oraz poziomem wykształcenia [5]. Różnica w wynikach prowadzonych badań może wynikać z faktu, że były one prowadzone w grupie osób dorosłych, w przeciwieństwie do aktualnych badań, które odnoszą się do opieki sprawowanej wobec matek oraz ich nowonarodzonych dzieci. W swoich badaniach dotyczących satysfakcji $\mathrm{z}$ opieki medycznej w oddziałach zachowawczych SPZOZ w Kraśniku w zależności od miejsca zamieszkania pacjentów Kos, Agnieszka Dziewa, Drop, Kawiak-Jachor analizowali jakość opieki pielęgniarskiej pod względem udzielanych informacji oraz wszelkich wyjaśnień ze strony personelu pielęgniarskiego. Zauważyli oni, że nie istnieje istotna statystycznie zależność, pomiędzy oceną poziomu zadowolenia badanych, a wsparciem ze strony personelu co zgodne jest $\mathrm{z}$ wynikami aktualnych badań [6]. Sochocka oraz Wojtyłko w swoich badaniach dotyczących poczucia satysfakcji podopiecznych Oddziału Chirurgii Dziecięcej WCM w Opolu określili jako nieistotny statystycznie okres trwania hospitalizacji dziecka w stosunku do poczucia bezpieczeństwa, które bezpośrednio związane jest $\mathrm{w}$ poczuciem zadowolenia z opieki [7]. Wyniki te zgodne są z wynikami uzyskanymi w aktualnych badaniach.

\section{Wnioski}

1. Średni poziom zadowolenia $\mathrm{z}$ opieki pielęgniarskiej oddziale oscylował w granicy maksymalnej ilości punktów do zdobycia, co oznacza, że prawie wszystkie $\mathrm{z}$ ankietowanych kobiet były bardzo zadowolone ze sprawowanej nad nimi i ich dziećmi opieki.

2. Na poziom zadowolenia $\mathrm{z}$ opieki i pozyskiwania informacji od personelu nie mają istotnego wpływu wybrane zmienne 
socjodemograficzne (wiek, wykształcenie, miejsce zamieszkania), czas hospitalizacji korzystanie ze wsparcia ze strony pielęgniarek.

\section{Zalecenia dla praktyki pielęgniarskiej}

Poziom satysfakcji badanych $\mathrm{z}$ opieki będzie wyższy, jeśli będzie wykonywana $\mathrm{z}$ uwzględnieniem obowiązujących standardów. Akt prawnywchodzący w życie na początku 2019 roku to rozporządzenie ministra zdrowia z dnia 16 sierpnia 2018 roku w sprawie standardu organizacyjnego opieki okołoporodowej. Zawiera on istotne zmiany w stosunku do poprzednich przepisów regulujących tę problematykę.

\section{Bibliografia/Bibliography:}

1. Alistair P. The evolution of neonatology, Department of Pediatrics, Division of Neonatal and Developmental Medicine, Stanford University School of Medicine, Palo Alto, CA 94304, 2005,(58),4:799-815.

2. Syweński E., Suchańska D., Dobrowolska D., Góralewicz- Lenartowicz R. Baran L., Berghausen -Mazur M. Płód jako pacjent. Perinatologia, Neonatologia i Ginekologia 2008,1,(4):314-318.

3. Rozporządzenie Ministra Zdrowia z dnia 16 sierpnia 2018 r. w sprawie standardu organizacyjnego opieki okołoporodowej. Poz. 1756.

4. Kołpa M., Jurkiewcz B., Sobyra A.: Wizerunek pielęgniarski oraz czynniki determinujące zadowolenie $\mathrm{z}$ opieki pielęgniarskiej na oddziale chirurgii jednego dnia. Pielęgniarstwo Chirurgiczne i Angilogiczne 2016,3:146-151.

5. Szpringer M., Chmielewski J., Kosecka J., Sobczyk B., Komendacka O. Poziom satysfakcji pacjentów jako jeden $\mathrm{z}$ aspektów jakości opieki medycznej. Medycyna Ogólna i Nauki o Zdrowiu 2015,21,(2):132-137. 
6. Kos M., Dziewa A., Drop B., Kawiak-Jawor E. Satysfakcja z opieki medycznej w oddziałach zachowawczych SPZOZ w Kraśniku w zależności od miejsca zamieszkania pacjentów, Medycyna Ogólna i Nauki o Zdrowiu,2016,22,(2):151-157.

7. Sochocka L., Wojtyłko A. Poczucie satysfakcji podopiecznych Oddziału Chirurgii Dziecięcej WCM w Opolu a model opieki funkcjonujący w Oddziale. Pielęgniarstwo i Zdrowie Publiczne 2011,1,(1):19-25.

Otrzymano: 12.02.2019r.

Zaakceptowano: 20.03.2019r. 